\title{
1 A novel Sporothrix brasiliensis genomic variant in Midwestern Brazil: 2 evidence for an older and wider sporotrichosis outbreak
}

4 João Eudes Filho ${ }^{a}$, Isabele Barbieri Santos ${ }^{b}$, Carmélia Matos Santiago Reis ${ }^{c}$, José Salvatori 5 Patané $^{d}$, Verenice Paredes ${ }^{e}$, João Paulo Romualdo ${ }^{e}$, Sabrina Santos Costa Poggianni ${ }^{f}$, Talita de 6 Cássia Borges Castro ${ }^{f}$, Oscar Mauricio Gomez ${ }^{g}$, Sandro Antonio Pereira ${ }^{h}$, Edvar Yuri Pacheco 7 Schubach ${ }^{i}$, Kamila Peres Gomes ${ }^{e}$, Heidi Mavengere ${ }^{j}$, Lucas Gomes de Brito Alves ${ }^{e}$, Joaquim 8 Lucas $^{a}$, Hugo Costa Paes ${ }^{e}$, Patricia Albuquerque ${ }^{l}$, Laurício Monteiro Cruz ${ }^{m}$, Juan G. McEwen ${ }^{g}$, 9 Jason E. Stajich ${ }^{n}$, Rodrigo Almeida-Paes ${ }^{h}$, Rosely Maria Zancopé-Oliveira ${ }^{h}$, Daniel R. Matute, 10 Bridget Barker ${ }^{o}$, Maria Sueli Soares Felipe ${ }^{a, p}$, Marcus de Melo Teixeira ${ }^{a, e, *}$, André Moraes

11 Nicola $^{a, e, *}$

$13{ }^{a}$ Graduate Program in Genomic Sciences and Biotechnology, Catholic University of Brasília,

\section{Brasília, Brazil.}

$15{ }^{b}$ Oswaldo Cruz Institute - Oswaldo Cruz Foundation (Fiocruz), Rio de Janeiro, Brazil.

$16{ }^{c}$ University Hospital of Brasília, Brasília, Distrito Federal

$17{ }^{d}$ Laboratório Especial de Ciclo Celular, Butantan Institute, São Paulo, Brazil

$18{ }^{e}$ Faculty of Medicine, University of Brasília, Brazil

$19{ }^{\mathrm{f}}$ Faculty of Agronomy and Veterinary Medicine, University of Brasília, Brasília, Brazil.

$20{ }^{g}$ Cellular \& Molecular Biology Unit, Corporación para Investigaciones Biológicas, Medellín, 21 Colombia

$22{ }^{h}$ Evandro Chagas National Institute of Infectious Diseases, Oswaldo Cruz Foundation, Rio de 23 Janeiro, Brazil.

$24{ }^{I}$ Coordination of Public Health Laboratories, Ministry of Health, Brasillia, Brazil.

$25{ }^{j}$ Department of Biology, University of North Carolina, Chapel Hill, US.

$26{ }^{\text {l}}$ Faculty of Ceilândia, University of Brasília, Brasília, Brazil.

$27{ }^{m}$ Office of Environmental Surveillance of Zoonoses, Federal District Health Secretariat, 28 Brasília, Brazil. 
medRxiv preprint doi: https://doi.org/10.1101/2020.07.09.20142125; this version posted July 11, 2020. The copyright holder for this preprint (which was not certified by peer review) is the author/funder, who has granted medRxiv a license to display the preprint in perpetuity. It is made available under a CC-BY-NC-ND 4.0 International license .

$29{ }^{n}$ Department of Microbiology \& Plant Pathology and Institute for Integrative Genome Biology,

30 University of California, Riverside, Riverside, USA.

$31{ }^{\circ}$ Pathogen and Microbiome Institute, Northern Arizona University, Flagstaff, USA

$32{ }^{p}$ Institute of Biological Sciences, University of Brasília, Brasília, Brazil.

$3{ }^{*}$ These authors share senior authorship

34

35 Corresponding authors:

36 Name: André Moraes Nicola

37 Address: Campus Universitário Darcy Ribeiro, Núcleo de Medicina Tropical, sala 40. Brasília-

38 DF, Brazil. 70910-900.

39 Phone: +5561992619048

40 E-mail: amnicola@unb.br

41

42 Name: Marcus de Melo Teixeira

43 Address: Campus Universitário Darcy Ribeiro, Núcleo de Medicina Tropical, sala 40. Brasília-

44 DF, Brazil. 70910-900.

45 Phone: +5561993992827

46 E-mail: marcus.teixeira@gmail.com

51 Sporotrichosis is a subcutaneous infection caused by fungi from the genus Sporothrix. The

52 disease is transmitted by inoculation of infective particles found in plant-contaminated material

53 or diseased animals, characterizing the classic sapronotic and emerging zoonotic transmission,

54 respectively. Since 1998, Brazil has experienced a zoonotic sporotrichosis epidemic due to $S$.

55 brasiliensis, centered in the state of Rio de Janeiro. Our observation of feline sporotrichosis cases

56 in Brasília (Midwestern Brazil), around 900 km away from Rio de Janeiro, led us to question 
medRxiv preprint doi: https://doi.org/10.1101/2020.07.09.20142125; this version posted July 11, 2020. The copyright holder for this preprint (which was not certified by peer review) is the author/funder, who has granted medRxiv a license to display the preprint in perpetuity.

It is made available under a CC-BY-NC-ND 4.0 International license .

57 whether the epidemic caused by S. brasiliensis has spread from the epicenter in Rio de Janeiro,

58 emerged independently in the two locations, or whether the disease has been present and

59 unrecognized in Midwestern Brazil. A retrospective analysis of 91 human and 4 animal cases

60 from Brasília, ranging from 1993 to 2018, suggests the occurrence of both sapronotic and

61 zoonotic transmission. Molecular typing identified S. schenckii as the agent in two animals and

62 all seven human patients from which we were able to recover clinical isolates. However, in two

63 animals, the disease was caused by $S$. brasiliensis. Whole-genome sequence typing of seven $S$.

64 brasiliensis strains suggests that isolates from Brasília are genetically distinct from those

65 obtained at the epicenter of the outbreak in Rio de Janeiro, both in phylogenomic and population

66 genomic analyses. The two $S$. brasiliensis populations seem to have separated $2.24-3.09$ million

67 years ago, indicating independent outbreaks or that the zoonotic S. brasiliensis outbreak might

68 have started earlier and be spread wider in South America than previously recognized.

Keywords: Sporothrix, Sporotrichosis, Sporothrix brasiliensis, Sporothrix schenckii, Zoonotic transmission, Brasília.

\section{Introduction}

74 The emergence of fungal pathogens worldwide is an important and frequently neglected

75 public health issue [1]. One of the most frequent genera of pathogenic fungi is Sporothrix

76 (Sordariomycetes, Ascomycota), which causes the subcutaneous granulomatous disease called

77 sporotrichosis. [2,3]. The etiologic agent of the disease, S. schenckii sensu lato, was recently

78 described to harbor three cryptic species: S. schenckii sensu stricto, S. globosa, and the emerging

79 species $S$. brasiliensis [4-6]. The three species are saprophytes and produce sympodial and

80 sessile conidia that switch their morphology to the pathogenic yeast phase after a transcutaneous

81 injury [7]. The three species differ in their virulence. S. brasiliensis is more virulent in animal

82 models than S. schenckii and S. globosa, and causes localized to disseminated sporotrichosis that

83 can be fatal to both humans and cats [8]. Lower antifungal susceptibility and refractory 
medRxiv preprint doi: https://doi.org/10.1101/2020.07.09.20142125; this version posted July 11, 2020. The copyright holder for this preprint

84 sporotrichosis occurs in some Brazilian cases related to the zoonotic epidemics $[9,10]$. Previous 85 population genetics surveys revealed that S. brasiliensis is largely clonal and the little variation

86 in the species is associated to particular geographic areas [6]. On the other hand, its sister taxon

87 S. schenckii shows higher rates of recombination and little to no population structure among

88 Brazilian strains [6].

Currently, sporotrichosis occurs endemically globally but it is especially prevalent in Latin America, South Africa, Madagascar, China, India, and Japan [3]. In addition to endemic

91 disease, multiple sporotrichosis outbreaks have been reported in the last century $[2,11,12]$.

92 Before the 1990s, sporotrichosis was considered a disease of low-to-moderate endemicity in

93 Brazil. In the past two decades, though, it has become an urgent health problem [7,13]. In 1997,

94 three individuals from the same family got infected by Sporothrix sp. after successive feline

95 zoonotic transmission events in Rio de Janeiro, Brazil [14]. Since 1998, over 5,100 cats have

96 been diagnosed with sporotrichosis in the state of Rio de Janeiro; > 5,000 human cases were

97 reported in 2015, suggesting high prevalence of the disease in the state [15]. Rio de Janeiro is

98 currently considered one of the three (along with China and South Africa) sporotrichosis

99 hyperendemic regions [14,16,17], with a crucial difference in incidence of feline sporotrichosis

100 and zoonotic transmission from cats to humans $[6,18]$.

101 Infections with S. brasiliensis have recently been described in Argentina and Paraguay,

102 the first reports of this species outside Brazil [19,20]. Sporotrichosis caused by S. brasiliensis has

103 recently been described in Northeast Brazil, also mostly due to zoonotic transmission [21-24].

104 The recent emergence of S. brasiliensis-associated sporotrichosis in places with few or no cases

105 reported in the early 2000s raises the question of whether the outbreak has recently spread from

106 Rio de Janeiro or zoonotic sporotrichosis cases had been happening there, unrecognized. This

107 question is very important in determining public health policy do deal with emergent

108 sporotrichosis. In this work, prompted by our observation in 2015 of a case of sporotrichosis in a

109 cat whose owner also had a lesion that was suggestive of the disease, we address this question.

110 To look for evidence of human zoonotic infections, we documented additional animal

111 cases and retrospectively studied a series of sporotrichosis cases in the University Hospital of

112 Brasília. We also sequenced the genomes of seven Sporothrix spp. strains and compared them to

113 the reference $S$. brasiliensis 5110 genome [25]. We report for the first time the occurrence of $S$.

114 brasiliensis infections in animals at the capital of Brazil, Brasília, located in the Midwestern 
medRxiv preprint doi: https://doi.org/10.1101/2020.07.09.20142125; this version posted July 11, 2020. The copyright holder for this preprint (which was not certified by peer review) is the author/funder, who has granted medRxiv a license to display the preprint in perpetuity.

It is made available under a CC-BY-NC-ND 4.0 International license .

115 portion of the country. We also found a surprising genomic diversity in the S. brasiliensis strains

116 in Brasília, which suggests that independent outbreaks caused by S. brasiliensis occur and might

117 have started earlier and be spread wider than previously recognized.

119 Material and Methods

120 Human cases

121 We carried out a cross-sectional study of a series of sporotrichosis cases in the University

122 Hospital of Brasília, from 1993 to 2018. This study was previously approved by the Ethics

123 Committee of the Faculty of Medicine, University of Brasília (protocol CAAE:

124 873718.0.00005558). The inclusion criterion was diagnosis of sporotrichosis by culture of

125 Sporothrix sp. in the Mycology Laboratory of the University Hospital of Brasília. Diagnoses

126 were performed by growing the fungus from biological samples (skin lesions, sputum, broncho-

127 alveolar lavage, and cerebrospinal fluid) on solid culture media (i.e. Sabouraud and Mycosel)

128 followed by microscopic characterization of colonies. The following data were anonymously

129 retrieved from patient medical records: clinical form of sporotrichosis (cutaneous, mucosal and

130 extracutaneous forms), address, year of diagnosis, age, sex, gender, race, occupation, treatment,

131 and disease outcome.

\section{Animal cases}

134 Three cats and one dog with suspected sporotrichosis from the Veterinary Hospital of the 135 University of Brasília, the Directorate for Environmental Surveillance (zoonosis division) of the

136 Federal District Health Department and a private veterinary clinic were referred to the Mycology

137 Laboratory of the University Hospital of Brasília for diagnosis between 2015 and 2018. We

138 performed direct microscopic observation of patient samples and cultured skin lesion specimens

139 as above, followed by microscopic identification of the fungus. Relevant clinical and

140 epidemiological data were also collected to describe the veterinary cases. Animal observations

141 and tests were previously approved by the University of Brasília Ethics Committee on the Use of

142 Animals (CEUA-UnB), protocol: 66716/2016. 
medRxiv preprint doi: https://doi.org/10.1101/2020.07.09.20142125; this version posted July 11, 2020. The copyright holder for this preprint (which was not certified by peer review) is the author/funder, who has granted medRxiv a license to display the preprint in perpetuity. It is made available under a CC-BY-NC-ND 4.0 International license .

\section{Morphological studies}

Seven isolates from humans and four isolates from animal cases were used for morphological and molecular characterization. Pure cultures were kept on Sabouraud dextrose agar at room temperature for the development and identification of the mycelial phase. The slide culture method was used to characterize microscopic filamentous features of the Sporothrix spp. isolates. Mycelia fragments were inoculated into $1 \mathrm{x} 1 \mathrm{~cm}$ Sabouraud dextrose agar and malt extract agar blocks, which were then mounted on a slide, covered with a coverslip and incubated for 14-21 days at room temperature. To induce the yeast phase, the mycelial fragments were inoculated into Brain-Heart Infusion broth and incubated for 7 days at $37{ }^{\circ} \mathrm{C}$ and $150 \mathrm{rpm}$ agitation. Both mycelial and yeast preparations were stained with lactophenol blue and visualized with a Zeiss AxioObserver Z1 microscope equipped with a 40X objective. Images were collected using the Zeiss ZEN software.

\section{Molecular typing and identification}

We extracted genomic DNA using the PureLink Genomic DNA Mini Kit (ThermoFisher). We started with $500 \mathrm{mg}$ of mycelial tissue as input material. We used glass beads protocol with a Precellys 24 instrument (Bertin). We assess the DNA integrity by running $5 \mu \mathrm{L}$ aliquot of the extraction on a in a $0.8 \%$ agar agarose-gel electrophoresis stained with 0.5 $\mu \mathrm{g} / \mathrm{ml}$ ethidium bromide. To estimate the DNA yield were we used a NanoDrop 1000c Instrument (ThermoFisher). We then amplified a segment of the calmodulin gene with PCR and Sanger sequenced in an ABI 3130xl Instrument (Applied Biosystems). PCR setting and cycling conditions were as previously described [6]. Initial nucleotide BLAST analysis (BLASTn) was performed for each amplicon in order to retrieve the best hit results for each strain on the NCBI database. All extractions $(\mathrm{N}=15)$ showed Sporothrix spp. as the closest BLAST match.

\section{Whole genome sequencing}

We selected six S. brasiliensis (A001, A005, s15677, s28606, s34180 and s48605) and one $S$. schenckii (A003) isolates for Illumina short read whole-genome sequencing. The two $S$. brasiliensis strains, A001 and A005, were retrieved from the collection at the Mycology Laboratory of the University Hospital of Brasília and labelled as SbFD (S. brasiliensis, Federal District). Isolates s15677, s28606, s34180 and s48605 were from the Collection of Pathogenic 
medRxiv preprint doi: https://doi.org/10.1101/2020.07.09.20142125; this version posted July 11, 2020. The copyright holder for this preprint (which was not certified by peer review) is the author/funder, who has granted medRxiv a license to display the preprint in perpetuity. It is made available under a CC-BY-NC-ND 4.0 International license .

175 Fungi at the Oswaldo Cruz Foundation, were obtained in the state of Rio de Janeiro and were

176 designated as SbRJ. From each isolate, we extracted $1 \mu \mathrm{g}$ of DNA, as described above. Next, we 177 prepared paired-end libraries using the NEBNext ${ }^{\circledR}$ Ultra $^{\mathrm{TM}}$ DNA Library Prep Kit for Illumina.

178 The libraries were quantified using the NEBNext ${ }^{\circ}$ Library Quant Kit for Illumina ${ }^{\circledR}(\mathrm{New}$

179 England Biolabs). We pooled equimolar amounts of each library together and sequenced them 180 using in an Illumina NextSeq 550 Instrument using the NextSeq 500/550 High Output Kit v2

181 chemistry. The run was performed in a high output, 2 X $150 \mathrm{bp}$ mode. We used Trimmommatic

182 [26] to remove adapters and filter low-quality bases.

\section{Public data}

We used three additional sets of Illumina paired-end reads from $S$. schenckii isolates from Colombia (EM7 and MS1 - [27]) and Puerto Rico (ATCC 58251 - [28]). To root phylogenetic trees (see below), we retrieved additional genomic assemblies from other Sporothrix species

188 from the NCBI genome browser (Supplementary Table 1).

\section{Read mapping and variant calling}

We mapped the newly-sequenced strains and the publicly available data to the $S$.

192 brasiliensis 5110 reference genome [29] using bwamem. To identify Mismatch intervals and 193 indels, we used GATK v3.3-0RealignerTargetCreator and IndelRealigner [30,31]. To identify

194 polymorphic sites (single nucleotide polymorphisms, SNP), we used the GATK

195 UnifiedGenotyper module using the parameter het $=0.01$ to account for a haploid organism. We 196 used the following filters to obtain SNPs calls: QD = 2.0 $\|$ FS_filter $=60.0 \|$ MQ_filter $=30.0 \|$

197 MQ_Rank_Sum_filter = -12.5 || Read_Pos_Rank_Sum_filter = -8 [32]. We excluded

198 polymorphic sites with less than 10X coverage, with less than $90 \%$ variant allele calls, or that 199 were identified by Nucmer [33] as located in duplicated regions in the S. brasiliensis reference 200 genome. We identified 115,488 SNPs across five Sporothrix species (16 isolates).

\section{Phylogenetic tree and whole-genome alignments}

203 We used the WGS dataset described above to build a phylogenetic tree of the 16

204 Sporothrix spp. isolates. We used IQTREE [34] to build a Maximum Likelihood (ML) tree with 205 the $-\mathrm{m}$ TEST function to determine the best nucleotide substitution model. To assess the strength 
medRxiv preprint doi: https://doi.org/10.1101/2020.07.09.20142125; this version posted July 11, 2020. The copyright holder for this preprint (which was not certified by peer review) is the author/funder, who has granted medRxiv a license to display the preprint in perpetuity. It is made available under a CC-BY-NC-ND 4.0 International license .

206 of the support for each clade present in the tree, we found the consensus phylogenomic tree of

207 1,000 ultrafast bootstraps coupled with 1,000 Shimodaira-Hasegawa-like approximate likelihood 208 ratio tests (SH-aLRT) [35,36]. We visualized the consensus topology and branch support with 209 FigTree v1.4.2 - http://tree.bio.ed.ac.uk/software/figtree/. We used the Automatic Assembly For 210 The Fungi (AAFTF) pipeline to assemble the newly-sequenced S. brasiliensis genomes, with 211 default parameters (https://github.com/stajichlab/AAFTF). The S. brasiliensis assemblies with

212 the highest N50 (Supplementary Table 1) were aligned to the strain 5110 reference genome using 213 the DGENIES online tool via minimap2 algorithm for comparative genomic purposes.

\section{Timing analysis}

216 Next, we estimated the approximate divergence time of the splits observed in the

217 phylogenomic analysis using Bayesian inference in BEAST v1.10.4 [37]. To avoid

218 overestimation of branch lengths which would tend to inflate molecular rates, a number of

219 invariable sites were input in the .xml files according to their frequency in the species genome's

220 composition and their base count of each type (A, C, G, and T) in the respective genome. We

221 used a GTR model with gamma variation among sites (using four discrete classes). Priors for the

222 different dating parameters included: a Normal distribution in which a conservative $90 \%$

223 confidence interval was within 3.8 - 4.9 MYA (following [25]) marking the separation between

224 S. brasiliensis and S. schecnkii; a rate interval of [0.9E-3, 16.7E-3] substitutions/site/branch/MY

225 for the parameter ucld.mean (mean of the uncorrelated lognormal distribution of rates across

226 branches, instead of assuming a more simplistic global clock prior), based on evolutionary rate

227 estimation based on different groups of fungi [38]; and a birth-death tree prior with incomplete

228 sampling [39]. We used two independent Markov Chain Monte Carlo (MCMC) chains each run

229 until convergence; the marginal distributions and traces from the two replicate chains were

230 inspected in Tracer v1.7 [40]. We summarized the two MCMC runs using LogCombiner

231 (BEAST package) after discarding the burnin region. Finally, we used Treeannotator (BEAST

232 package) to annotate clade posteriors, divergence times, and rate variation across branches.

\section{Population genetic analysis}

235 We estimated the average nucleotide diversity $(\pi)$ within species or populations and absolute 236 differentiation $\left(D_{x y}\right)$ between $S$. brasiliensis and S. schenckii, and between the S. brasiliensis 
medRxiv preprint doi: https://doi.org/10.1101/2020.07.09.20142125; this version posted July 11, 2020. The copyright holder for this preprint (which was not certified by peer review) is the author/funder, who has granted medRxiv a license to display the preprint in perpetuity. It is made available under a CC-BY-NC-ND 4.0 International license .

237 SbFD and SbRJ using a series of Python scripts available at

238 https://github.com/simonhmartin/genomics_general.

Results

Both sapronotic and zoonotic transmissions of sporotrichosis occur in Brasillia and surrounding areas

The study population involved 91 human cases ranging from 1 to 82 years of age with

245 of the University Hospital of Brasília. All patients were diagnosed either by direct exam or by

246 the microbiological isolation of the pathogen from 1993 to 2018 . We reported 64 cases (70\%) in

247 males and $27(30 \%)$ females. The years with most cases reported were 1999, 2000, and 2009

248 with $12(13 \%), 7(8 \%)$, and $8(9 \%)$ cases, respectively. Regarding age groups, the 21-30- and 51-

249 60-year ranges have more cases in this retrospective study, corresponding to 17 (18.7\%) and 16

$250(17.6 \%)$ cases, respectively (Table 1). Most patients were treated with itraconazole alone or in

251 association with saturated potassium iodide and, in severe cases, fluconazole and/or

252 amphotericin B were used.

We were able to analyze 48 full medical records of the included patients. Among them,

25434 were presumably infected in Brasília (70.9\%) and six in the neighboring state of Goiás

255 (12.5\%). Most patients had the lymphocutaneous form $(n=34-70.8 \%)$, followed by fixed

256 cutaneous form $(n=6-12.6 \%)$. Five extra-cutaneous cases were detected in the central nervous

257 system $(n=1-2 \%)$ and or the upper airway tract $(n=4-8.3 \%)$. The clinical presentation of three

258 patients $(6.3 \%)$ was inconclusive or not reported. The most frequent profession/occupation was

259 student $(n=26-29 \%)$, followed by farmers and retirees with 15\% $(n=14)$ and 14\% $(n=13)$,

260 respectively (Table 1). Some risk factors we found were prostate and breast cancer, high blood

261 pressure, diabetes, cirrhosis, tuberculosis, leishmaniosis, hepatitis and other chronic diseases.

262 Chagas disease and paracoccidioidomycosis co-infections were found in two sporotrichosis

263 patients. Three cases of HIV coinfection were also diagnosed. Three cases were fatal, two of

264 which in patients with cancer and one with chronic cirrhosis.

265 Additionally, a thorough investigation of the clinical records suggested two main forms

266 of Sporothrix infections in Brasília: (1) the classical sapronotic form acquired from a direct 
medRxiv preprint doi: https://doi.org/10.1101/2020.07.09.20142125; this version posted July 11, 2020. The copyright holder for this preprint (which was not certified by peer review) is the author/funder, who has granted medRxiv a license to display the preprint in perpetuity. It is made available under a CC-BY-NC-ND 4.0 International license .

267 inoculation of plant-derived material harboring the fungus, which was more observed in rural

268 and construction workers, and (2) the zoonotic transmission triggered by skin injuries provoked 269 by infected cat or dog bite/scratches. Sapronotic sporotrichosis was reported in 5 patients (10\%)

270 after injuries with plant-derived material. Five patients (10\%), including two veterinarians,

271 reported cat/dog bites or scratches and six other patients (12.6\%) reported living and having

272 frequent contact with dogs or cats with skin lesions. Other patients either did not report any

273 previous injuries or reported a different exposure source (i.e. sporotrichosis acquired after

274 injuries with barbed wire and metal cans).

275 In parallel, we diagnosed, from 2015 to 2018, 4 animals (3 cats and 1 dog) with

276 sporotrichosis in Brasília. These animals had classical clinical presentations such as multiple

277 suppurative granulomatous cutaneous lesions with a high load of yeast cells, generally with

278 involvement of mucous membranes. Lesions were commonly found at parts such as the head,

279 especially on the nose, as well as on the chest and legs. Two felines were euthanized and the

280 other cat and the dog were treated with itraconazole and potassium iodide. Lastly, the pet owner

281 of the cat in which the A001 strain was recovered, was also diagnosed with cutaneous

282 sporotrichosis. The diagnosis and treatment were made in another hospital in Brasília, so we do

283 not have medical records or a clinical isolate obtained from the owner.

Sporothrix brasiliensis isolates from Brasilia and the epicenter of the zoonotic sporotrichosis epidemics, Rio de Janeiro, are genetically distinct.

In order to differentiate between two different hypotheses for S. brasiliensis presence in Brasília, that it was recently introduced here from Southeast Brazil or that the Brasília isolates are actually endemic to that region, we performed a number of genetics and genomics analyses.

290 First, we inferred the genealogical relationships between isolates of different species of

291 Sporothrix using whole genome sequencing. By rooting our tree with S. insectorum, we observed

292 that S. schenckii and S. brasiliensis are sister species and form a triad along with S. globosa

293 (Figure 2). The Most Recent Common Ancestor (tMRCA) of Sporothrix emerged between 26.63

294 and 37.38 Million Years Ago (MYA) (Figure 3). Unlike S. insectorum and S. pallida, this triad

295 of species cause sporotrichosis in humans and animals and form the "Sporothrix pathogenic

296 clade". The crown age of this pathogenic group (TMRCA) is between 4.24 - 5.28 MYA. The 
medRxiv preprint doi: https://doi.org/10.1101/2020.07.09.20142125; this version posted July 11, 2020. The copyright holder for this preprint (which was not certified by peer review) is the author/funder, who has granted medRxiv a license to display the preprint in perpetuity. It is made available under a CC-BY-NC-ND 4.0 International license .

divergence between the pathogenic clade and S. pallida occurred 10.22 - 14.09 MYA, suggesting that the pathogenesis syndrome must have arisen in the last 15 MY.

Our WGS phylogenetic tree also allows us to assess the partition of the genetic variation

300 within S. schenckii. We found support for the existence of two clades, one harboring two

301 Colombian isolates (SsEM7 and SsMS1) and a cat-derived isolate from Brasília (A003) and a

302 clade composed by one strain from the USA (1099-18) and an additional strain from Puerto Rico

303 (ATCC 58251). We estimate that divergence of these two groups occurred between 4.42 and

3045.82 MYA. These results suggest that South American and North American populations of $S$.

305 schenckii are genetically differentiated and call for the question of whether there has been

306 speciation associated with geographical distribution within S. schenckii.

307 Next, we studied the relationships between the S. brasiliensis isolates from Brasília and

308 Rio de Janeiro. The five Rio de Janeiro isolates (5110, s15677, s28606, s34180 and s48605)

309 form a monophyletic group that does not include the two Brasília isolates, A001 and A005,

310 which in turn are clustered in their own group. We also compared genomic similarities between

311 the two $S$. brasiliensis cluster variants by aligning one individual from each cluster to the 5110

312 reference strains using the minimap2 tool. By aligning the S. brasiliensis strain s15677 to the $S$.

313 brasiliensis 5110 reference strain (both belonging to the Rio de Janeiro population), we observed

314 that the genomes are $99.81 \%$ similar. By aligning the $S$. brasiliensis A001 strain to the same

315 reference, the genomic similarity dropped to $96.31 \%$ suggesting that those two groups are

316 genetically unrelated (Supplementary Figure 1).

317 We calculated the approximate divergence time between S. brasiliensis isolates from

318 Brasília and Southeastern Brazil. The TMRCA of the S. brasiliensis species was estimated to be

3192.24 - 3.09 MYA, the TMRCA for the strains from Rio de Janeiro is 1.94-2.7 MYA, and the

320 TMRCA for the strains from Brasília was 0.52-0.93 MYA (Figure 3). The S. brasiliensis isolates

321 A001 and A005 are clustered in a single branch and are phylogenetically different from those

322 isolated in Rio de Janeiro (5110, s15677, s28606, s34180 and s48605 - Figure 2). This result

323 suggests that those infections were likely to be locally acquired in Brasília, not in Rio de Janeiro.

324 These results suggest that the two populations are genetically distinct and that the infections

325 observed in Brasília are not the result of a small group of Rio de Janeiro isolates that migrated.

326 Since the infections caused by S. brasiliesis in Brasília happened autochthonously, the causal 
medRxiv preprint doi: https://doi.org/10.1101/2020.07.09.20142125; this version posted July 11, 2020. The copyright holder for this preprint (which was not certified by peer review) is the author/funder, who has granted medRxiv a license to display the preprint in perpetuity. It is made available under a CC-BY-NC-ND 4.0 International license .

327 agent of these infections is genomically differentiated from the causal agent of the Rio de Janeiro 328 infections.

We evaluate a second prediction of the hypothesis that Rio de Janeiro isolates caused the Brasília outbreak. The source population of the outbreak should have a larger genetic diversity than the outbreak population because the former has not undergone a bottleneck. We measured the magnitude of genetic variation in each Sporothrix group using pairwise calculations of heterozygosity. S. schenckii has the highest nucleotide diversity $(\pi=1.67 \%)$, which is in line with the measurements of other fungal species with complex population composition and worldwide distribution [41,42]. The genetic variation within $S$. brasiliensis has much lower nucleotide diversity $(\pi=0.52 \%)$ than that of its sister species, probably due to its endemicity to South America. We next calculated the nucleotide diversity within the two Brazilian S. brasiliensis groups. The Brasília group has a nucleotide diversity on the same order of magnitude as $S$. brasiliensis as a whole $(\pi=0.20 \%)$. On the other hand, the Rio de Janeiro population has an extremely low genetic diversity $\left(\pi=9.78 \times 10^{-4} \%\right)$, suggesting an extreme bottleneck. In agreement with our inference from the phylogenomic tree, these results indicate that the Brasília population is extremely unlikely to be derived from the Rio de Janeiro one.

Our phylogenetic tree suggested genetic differentiation between $S$. brasiliensis isolates

344 from Rio de Janeiro and Brasília. We calculated the pairwise absolute genetic distance $\left(D_{x y}\right)$

345 between $S$. schenckii and S. brasiliensis, and within S. brasiliensis. The $D_{x y}$ between those two

346 species was 0.042 while between the Brasília and Rio de Janeiro populations it was 0.010. Figure

3473 shows the mean pairwise differences per site within populations (nucleotide diversity or $\pi$ ) and 348 mean pairwise differences per site between populations $D_{x y}$ along the 13 scaffolds of the

349 Sporothrix genome. The genome differentiation between S. schenckii and S. brasiliensis is

350 extensive and widespread along the whole genome. We observed a strikingly different pattern

351 when we compare the two populations of S. brasiliensis. As expected, Rio de Janeiro $S$.

352 brasiliensis has little genetic variation along the whole genome (Figure 3A). The $D_{x y}$ along most

353 of the genome is low suggesting low differentiation between Rio de Janeiro and Brasília despite

354 almost $1 \mathrm{MY}$ of divergence (See above, Figure 2). Nonetheless, scaffolds I, III, V, IX and XI,

355 show peaks of high differentiation. Notably, the $D_{x y}$ peaks in scaffolds I, III, and XI are highly

356 differentiated between Rio de Janeiro and Brasília S. brasiliensis and between S. brasiliensis (as

357 a whole) and S. schenckii. These results suggest that the differentiation between Brazilian 
medRxiv preprint doi: https://doi.org/10.1101/2020.07.09.20142125; this version posted July 11, 2020. The copyright holder for this preprint (which was not certified by peer review) is the author/funder, who has granted medRxiv a license to display the preprint in perpetuity. It is made available under a CC-BY-NC-ND 4.0 International license .

populations of $S$. brasiliensis is modest and localized and not as pronounced as between $S$. schenckii and S. brasiliensis. This difference might simply stem from the difference in divergence time between the Sporothrix species and the S. brasiliensis populations.

\section{Discussion}

Sporotrichosis due to $S$. brasiliensis has become one of the most important fungal diseases in Brazil. The disease has gone from a localized outbreak in Rio de Janeiro state to a country-wide epidemic during the past 20 years and has affected thousands of humans and animals. In Brasília, located in Midwestern Brazil and roughly $900 \mathrm{~km}$ from Rio de Janeiro, we observed indications that suggest cat/dog-transmitted sporotrichosis might occur. Moreover, both cats and dogs are affected by pathogenic Sporothrix spp. In Rio de Janeiro, both fungal species have been isolated from dogs [18], but $S$. brasiliensis has been identified in almost all cats tested so far [16]. The etiologic agent of this disease was recently found in clinical and environmental samples in Argentina as well in veterinary samples in Paraguay [19,20].

In this study, we dissect the support for two different hypotheses for the expansion of this disease throughout South America, namely that $S$. brasiliensis recently ( $<20$ years) spread from Rio de Janeiro to other areas in Brazil and other countries via human, animal hosts or fomites; or that different groups of S. brasiliensis occur in different locations of the South American continent. We focused on a recent sporotrichosis case series in Brasília. If the former hypothesis is correct, one would expect that the Rio de Janeiro population would have a larger genetic variation than the Brasília population. Additionally, one would expect the Rio de Janeiro population to encompass the genetic variants observed in Brasília. Neither of these were observed in our data. The nucleotide diversity $(\pi)$ in Rio de Janeiro is 200 times lower than in Brasília. Additionally, the Rio de Janeiro and Brasília populations are reciprocally monophyletic which contradicts the idea that Brasília strains are a subset of the Rio de Janeiro group. Moreover, the split time between Brasília and Rio de Janeiro occurred between 0.52-0.93 MYA, predating the human colonization of the Americas and thus precluding the possibility that $S$.

384 brasiliensis migrated associated with humans.

The observation that the surge on sporotrichosis in Brasília is not caused by recent migration from Rio de Janeiro poses two additional questions. First, other reasons, besides

387 migration must be responsible for the recent uptick of cases. One possibility is that deforestation 388 and human expansion into previously uninhabited areas has put humans (and their pets) in 
medRxiv preprint doi: https://doi.org/10.1101/2020.07.09.20142125; this version posted July 11, 2020. The copyright holder for this preprint (which was not certified by peer review) is the author/funder, who has granted medRxiv a license to display the preprint in perpetuity. It is made available under a CC-BY-NC-ND 4.0 International license .

contact with fungi that otherwise had never infected humans. A second possibility is that in the last 20 years, a previously tamed lineage of $S$. brasiliensis became more virulent. Both novel mutation and introgression from a virulent lineage could be responsible. Finally, it is possible

392 that the improvement of epidemiology and medical observations has led to the identification and

393 recording of sporotrichosis due to S. brasiliensis.

Second, it remains unclear why the number of cases in Brasilia is lower than that in Rio de Janeiro, one of the most hyperendemic areas in the world. One potential explanation for the higher incidence of sporotrichosis in Rio de Janeiro than Brasília is higher population density and less favorable sanitation conditions in the former area [17]. Our study shows that cats can acquire sporotrichosis caused by both $S$. schenckii and $S$. brasiliensis, which indicates that feral and stray cats can be reservoirs of the disease. Another possibility is that Brasilia and Rio de Janeiro differ in their number of outdoor cats. Studies have shown a high prevalence of

401 parasitosis in cats from both locations (Brasilia: [43], RJ:[44]) but the number of felines and their 402 relative health conditions remain unknown.

Our work suggests the existence of at least two groups of $S$. brasiliensis in South

404 America. The increase in sporotrichosis incidence, along with the increments on the disease

405 burden of other mycoses across the world, and the recent outbreak of Cryptococcus gattii -

406 originated in the Amazon region - in the Pacific Northwest [45] are sobering indications of the

407 importance of efforts to detect and mitigate or prevent the spread of fungal emerging diseases,

408 both in South America and elsewhere.

\section{Acknowledgments}

The authors would like to thank to Jéssica S. Boechat and Manoel M. E. Oliveira

413 (Fiocruz) for the technical support. A.M.N was funded by FAP-DF awards 0193.001048/2015-

414 0193.001561/2017 and the CNPq grant 437484/2018-1. B.M.B. was supported by NIH/NIAID

415 award R21AI28536. D.R.M. was supported by NIH/NIGMS award R01GM121750. M.M.T was

416 supported by CNPq/UNIVERSAL award 43460/2018-2. M.S.S.F was supported by FAP-

417 DF/PRONEX award 193.001.533/2016. S.A.P. was supported by FAPERJ, grant number E$418 \quad 26 / 202.737 / 2019$ 
medRxiv preprint doi: https://doi.org/10.1101/2020.07.09.20142125; this version posted July 11, 2020. The copyright holder for this preprint (which was not certified by peer review) is the author/funder, who has granted medRxiv a license to display the preprint in perpetuity. It is made available under a CC-BY-NC-ND 4.0 International license .

\section{References}

1. Fisher MC, Gurr SJ, Cuomo CA, et al. Threats Posed by the Fungal Kingdom to Humans, Wildlife, and Agriculture. mBio. 2020 May 5;11(3).

2. Zhang $Y$, Hagen $F$, Stielow $B$, et al. Phylogeography and evolutionary patterns in Sporothrix spanning more than 14000 human and animal case reports. Persoonia. 2015 Dec;35:1-20.

3. Chakrabarti A, Bonifaz A, Gutierrez-Galhardo MC, et al. Global epidemiology of sporotrichosis. Med Mycol. 2015 Jan;53(1):3-14.

4. Marimon R, Cano J, Gene J, et al. Sporothrix brasiliensis, S. globosa, and S. mexicana, three new Sporothrix species of clinical interest. J Clin Microbiol. 2007 Oct;45(10):3198206.

5. Rodrigues AM, de Hoog GS, de Camargo ZP. Sporothrix Species Causing Outbreaks in Animals and Humans Driven by Animal-Animal Transmission. PLoS Pathog. 2016 Jul;12(7):e1005638.

6. Teixeira Mde M, Rodrigues AM, Tsui CK, et al. Asexual propagation of a virulent clone complex in a human and feline outbreak of sporotrichosis. Eukaryot Cell. 2015 Feb;14(2):158-69.

7. Orofino-Costa R, Macedo PM, Rodrigues AM, et al. Sporotrichosis: an update on epidemiology, etiopathogenesis, laboratory and clinical therapeutics. An Bras Dermatol. 2017 Sep-Oct;92(5):606-620.

8. Della Terra PP, Rodrigues AM, Fernandes GF, et al. Exploring virulence and immunogenicity in the emerging pathogen Sporothrix brasiliensis. PLoS Negl Trop Dis. 2017 Aug;11(8):e0005903.

9. Almeida-Paes R, Oliveira MME, Freitas DFS, et al. Refractory sporotrichosis due to Sporothrix brasiliensis in humans appears to be unrelated to in vivo resistance. Med Mycol. 2017 Jul 1;55(5):507-517.

10. Galhardo MC, De Oliveira RM, Valle AC, et al. Molecular epidemiology and antifungal susceptibility patterns of Sporothrix schenckii isolates from a cat-transmitted epidemic of sporotrichosis in Rio de Janeiro, Brazil. Med Mycol. 2008 Mar;46(2):141-51.

11. Govender NP, Maphanga TG, Zulu TG, et al. An Outbreak of Lymphocutaneous Sporotrichosis among Mine-Workers in South Africa. PLoS Negl Trop Dis. 2015 Sep;9(9):e0004096.

12. Coles FB, Schuchat A, Hibbs JR, et al. A multistate outbreak of sporotrichosis associated with sphagnum moss. Am J Epidemiol. 1992 Aug 15;136(4):475-87.

13. Queiroz-Telles F, Fahal AH, Falci DR, et al. Neglected endemic mycoses. Lancet Infect Dis. 2017 Nov;17(11):e367-e377.

14. de Lima Barros MB, Schubach TM, Galhardo MC, et al. Sporotrichosis: an emergent zoonosis in Rio de Janeiro. Mem Inst Oswaldo Cruz. 2001 Aug;96(6):777-9.

15. Gremiao IDF, Oliveira MME, Monteiro de Miranda LH, et al. Geographic Expansion of Sporotrichosis, Brazil. Emerg Infect Dis. 2020 Mar;26(3):621-624.

16. Boechat JS, Oliveira MME, Almeida-Paes $R$, et al. Feline sporotrichosis: associations between clinical-epidemiological profiles and phenotypic-genotypic characteristics of 
medRxiv preprint doi: https://doi.org/10.1101/2020.07.09.20142125; this version posted July 11, 2020. The copyright holder for this preprint (which was not certified by peer review) is the author/funder, who has granted medRxiv a license to display the preprint in perpetuity. It is made available under a CC-BY-NC-ND 4.0 International license .

the etiological agents in the Rio de Janeiro epizootic area. Mem Inst Oswaldo Cruz. 2018 Mar;113(3):185-196.

17. Gremiao ID, Miranda LH, Reis EG, et al. Zoonotic Epidemic of Sporotrichosis: Cat to Human Transmission. PLoS Pathog. 2017 Jan;13(1):e1006077.

18. Rodrigues AM, de Melo Teixeira M, de Hoog GS, et al. Phylogenetic analysis reveals a high prevalence of Sporothrix brasiliensis in feline sporotrichosis outbreaks. PLoS Negl Trop Dis. 2013;7(6):e2281.

19. Cordoba S, Isla G, Szusz W, et al. Molecular identification and susceptibility profile of

\section{García Duarte JM, Wattiez Acosta VR, Fornerón Viera PML, et al. Esporotricosis} trasmitida por gato doméstico. Reporte de un caso familiar. Revista del Nacional (Itauguá). 2017;9:67-76.

21. Silva GM, Howes JCF, Leal CAS, et al. Surto de esporotricose felina na região metropolitana do Recife. Pesquisa Veterinária Brasileira. 2018;38:1767-1771.

22. Nunes GDL, Carneiro RS, Filgueira KD, et al. ESPOROTRICOSE FELINA NO MUNICÍPIO DE ITAPORANGA, ESTADO DA PARAÍBA, BRASIL: RELATO DE UM CASO. Arquivos de Ciências Veterinárias e Zoologia da UNIPAR. 2011;14(2):5.

23. Marques-Melo EH, Lessa DFdS, Nunes ACBT, et al., editors. Felino doméstic como agente transmissor de esprotricose para humano: relato ddo primeiro caso no estado de alagoas2014.

24. Filgueira KD. Esporotricose na espécie canina: relato de um caso na cidade de Mossoró, RN

. Ciência Animal Brasileira. 2009;10(2):5.

25. Teixeira MM, de Almeida LG, Kubitschek-Barreira $P$, et al. Comparative genomics of the major fungal agents of human and animal Sporotrichosis: Sporothrix schenckii and Sporothrix brasiliensis. BMC Genomics. 2014;15:943.

26. Bolger AM, Lohse $M$, Usadel B. Trimmomatic: a flexible trimmer for Illumina sequence data. Bioinformatics. 2014 Aug 1;30(15):2114-20.

27. Gomez OM, Alvarez LC, Munoz JF, et al. Draft Genome Sequences of Two Sporothrix schenckii Clinical Isolates Associated with Human Sporotrichosis in Colombia. Genome Announc. 2018 Jun 14;6(24).

28. Cuomo CA, Rodriguez-Del Valle N, Perez-Sanchez L, et al. Genome Sequence of the Pathogenic Fungus Sporothrix schenckii (ATCC 58251). Genome Announc. 2014 May $22 ; 2(3)$.

29. Li H, Durbin R. Fast and accurate short read alignment with Burrows-Wheeler transform. Bioinformatics. 2009 Jul 15;25(14):1754-60.

30. DePristo MA, Banks $E$, Poplin $R$, et al. A framework for variation discovery and genotyping using next-generation DNA sequencing data. Nat Genet. 2011 May;43(5):491-8.

31. McKenna A, Hanna M, Banks E, et al. The Genome Analysis Toolkit: a MapReduce framework for analyzing next-generation DNA sequencing data. Genome Res. 2010 Sep;20(9):1297-303. 
medRxiv preprint doi: https://doi.org/10.1101/2020.07.09.20142125; this version posted July 11, 2020. The copyright holder for this preprint

(which was not certified by peer review) is the author/funder, who has granted medRxiv a license to display the preprint in perpetuity.

It is made available under a CC-BY-NC-ND 4.0 International license .

32. Teixeira MM, Alvarado P, Roe CC, et al. Population Structure and Genetic Diversity among Isolates of Coccidioides posadasii in Venezuela and Surrounding Regions. mBio. 2019 Nov 26;10(6).

33. Kurtz S, Phillippy A, Delcher AL, et al. Versatile and open software for comparing large genomes. Genome Biol. 2004;5(2):R12.

34. Nguyen LT, Schmidt HA, von Haeseler A, et al. IQ-TREE: a fast and effective stochastic algorithm for estimating maximum-likelihood phylogenies. Mol Biol Evol. 2015 Jan;32(1):268-74.

35. Minh BQ, Nguyen MA, von Haeseler A. Ultrafast approximation for phylogenetic bootstrap. Mol Biol Evol. 2013 May;30(5):1188-95.

36. Guindon S, Dufayard JF, Lefort V, et al. New algorithms and methods to estimate maximum-likelihood phylogenies: assessing the performance of PhyML 3.0. Syst Biol. 2010 May;59(3):307-21.

37. Suchard MA, Lemey $P$, Baele $G$, et al. Bayesian phylogenetic and phylodynamic data integration using BEAST 1.10. Virus Evol. 2018 Jan;4(1):vey016.

38. Kasuga T, White TJ, Taylor JW. Estimation of nucleotide substitution rates in Eurotiomycete fungi. Mol Biol Evol. 2002 Dec;19(12):2318-24.

39. Stadler T. On incomplete sampling under birth-death models and connections to the sampling-based coalescent. J Theor Biol. 2009 Nov 7;261(1):58-66.

40. Rambaut A, Drummond AJ, Xie D, et al. Tracer v1.7. 2018.

41. Matute DR, Sepulveda VE. Fungal species boundaries in the genomics era. Fungal Genet Biol. 2019 Jul 4;131:103249.

42. Leffler EM, Bullaughey K, Matute DR, et al. Revisiting an old riddle: what determines genetic diversity levels within species? PLoS Biol. 2012;10(9):e1001388.

43. Aquino LC, Hicks CA, Scalon MC, et al. Prevalence and phylogenetic analysis of haemoplasmas from cats infected with multiple species. J Microbiol Methods. 2014 Dec;107:189-96.

44. Macieira DB, de Menezes Rde C, Damico CB, et al. Prevalence and risk factors for hemoplasmas in domestic cats naturally infected with feline immunodeficiency virus and/or feline leukemia virus in Rio de Janeiro--Brazil. J Feline Med Surg. 2008 Apr;10(2):120-9.

45. Hagen F, Ceresini PC, Polacheck I, et al. Ancient dispersal of the human fungal pathogen Cryptococcus gattii from the Amazon rainforest. PLoS One. 2013;8(8):e71148. 
medRxiv preprint doi: https://doi.org/10.1101/2020.07.09.20142125; this version posted July 11, 2020. The copyright holder for this preprint (which was not certified by peer review) is the author/funder, who has granted medRxiv a license to display the preprint in perpetuity.

It is made available under a CC-BY-NC-ND 4.0 International license.

\section{Tables}

540 Table 1 - Epidemiological characteristics of sporotrichosis in Brasília, Brazil

\begin{tabular}{|l|l|}
\hline Gender (n=91) & \\
\hline Male & $64(70.32 \%)$ \\
\hline Female & $27(29.68 \%)$ \\
\hline Profession (n=91) & \\
\hline Students & $26(28.57 \%)$ \\
\hline Rural Worker & $14(15.38 \%)$ \\
\hline Household/retired & $13(14.28 \%)$ \\
\hline Veterinary & $2(2.2 \%)$ \\
\hline Other & $4(4.39 \%)$ \\
\hline Not reported & $32(35.18 \%)$ \\
\hline HIV condition (n=91) & \\
\hline positive & $3(3.29 \%)$ \\
\hline negative & $88(96.71 \%)$ \\
\hline Age Group (n=91) & \\
\hline 0 - 10 & $12(13.19 \%)$ \\
\hline 11 - 20 & $10(10.99 \%)$ \\
\hline 21 - 30 & $17(18.68 \%)$ \\
\hline 31 - 40 & $11(12.09 \%)$ \\
\hline 41 - 50 & $11(12.09 \%)$ \\
\hline 51 - 60 & $16(17.58 \%)$ \\
\hline$>61$ & $14(15.38 \%)$ \\
\hline Sporotrichosis forms (n=48) & $6(12.5 \%)$ \\
\hline Cutaneous fixed & $34(70.83 \%)$ \\
\hline Lymphocutaneous & $5(10.42 \%)$ \\
\hline Disseminated & $3(6.25 \%)$ \\
\hline Unknown & \\
\hline Source of infection $(\mathbf{n = 4 8 )}$ & \\
\hline & \\
\hline
\end{tabular}


medRxiv preprint doi: https://doi.org/10.1101/2020.07.09.20142125; this version posted July 11, 2020. The copyright holder for this preprint (which was not certified by peer review) is the author/funder, who has granted medRxiv a license to display the preprint in perpetuity. It is made available under a CC-BY-NC-ND 4.0 International license.

\begin{tabular}{|l|ll|}
\hline Living with a cat or dog & $6(12.25 \%)$ & 541 \\
\hline Cat/dog bite or scratch & $5(10.42 \%)$ & 542 \\
\hline Trauma with plant/wood material & $5(10.42 \%)$ & \\
\hline Unknown & $32(66.91 \%)$ & \\
\hline
\end{tabular}




\section{Figures}

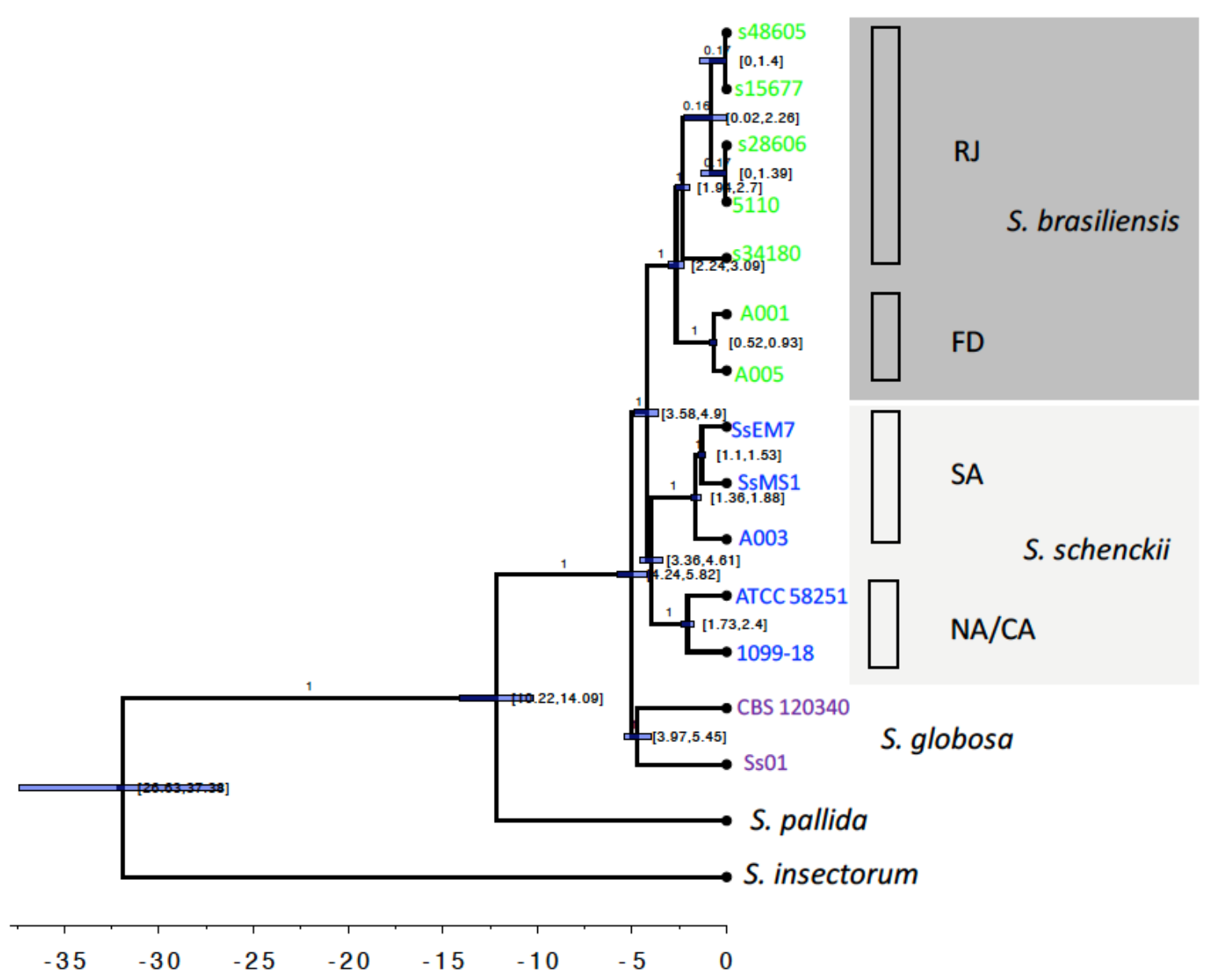

545 Figure 1 - Whole-genome Sporothrix genealogy using BEAST analyses. The phylogenomic tree

546 was inferred using Bayesian inference under the GTR model with gamma variation among sites

547 and $S$. insectorum was set as the outgroup. The $90 \%$ confidence interval marking the separation

548 between $S$. brasiliensis and S. schenckii was set to 3.8 - 4.9 MYA, a rate interval of [0.9E-3,

549 16.7E-3] based on evolutionary rate estimation based on different groups of fungi and a birth-

550 death tree prior with incomplete sampling were set as priors. The clade distribution, posterior

551 probabilities and divergence times are shown. 


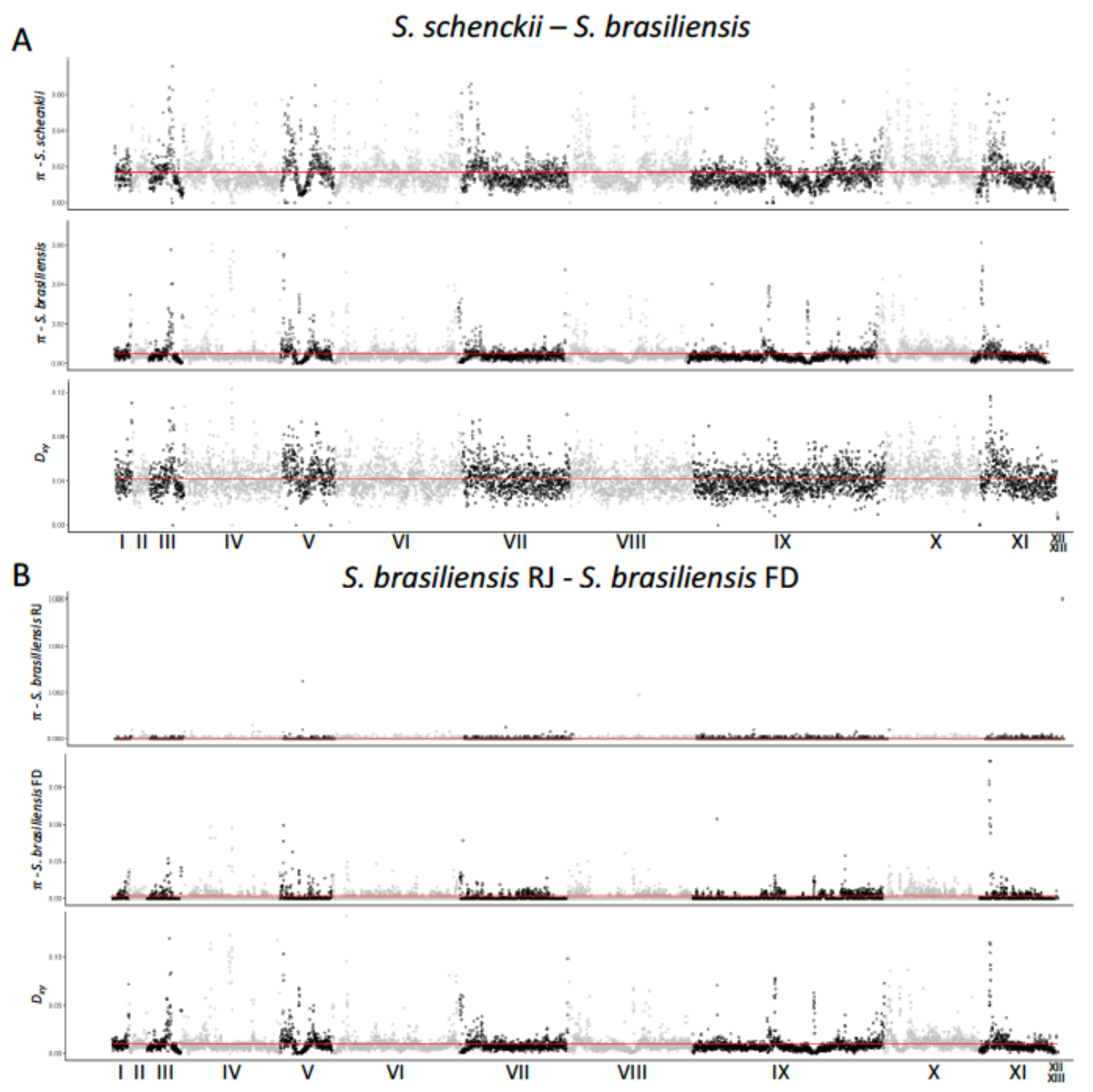

553 Figure 2 - Population genetics plots along the S. brasiliensis 5110 reference genome. We have

554 calculated the mean nucleotide diversity $(\pi)$ within species or populations and absolute

555 differentiation $\left(D_{x y}\right)$ between $S$. brasiliensis and S. schenckii, and between the S. brasiliensis

556 SbFD and SbRJ (red line) and plotted along each scaffold of the S. brasiliensis 5110 genome

557 using a $5 \mathrm{~kb}$ window. 
medRxiv preprint doi: https://doi.org/10.1101/2020.07.09.20142125; this version posted July 11, 2020. The copyright holder for this preprint (which was not certified by peer review) is the author/funder, who has granted medRxiv a license to display the preprint in perpetuity.

It is made available under a CC-BY-NC-ND 4.0 International license .

A

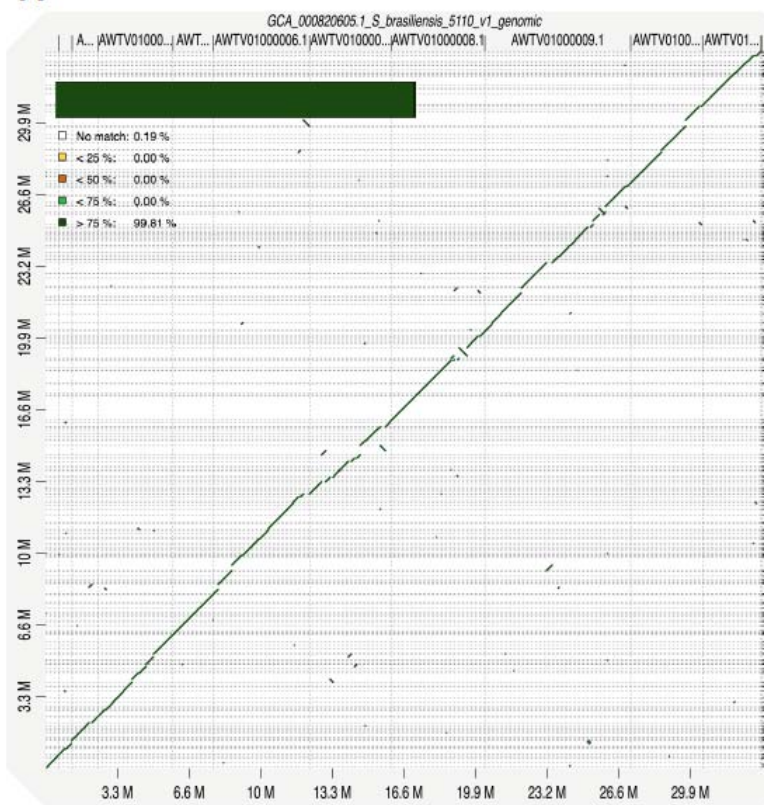

B

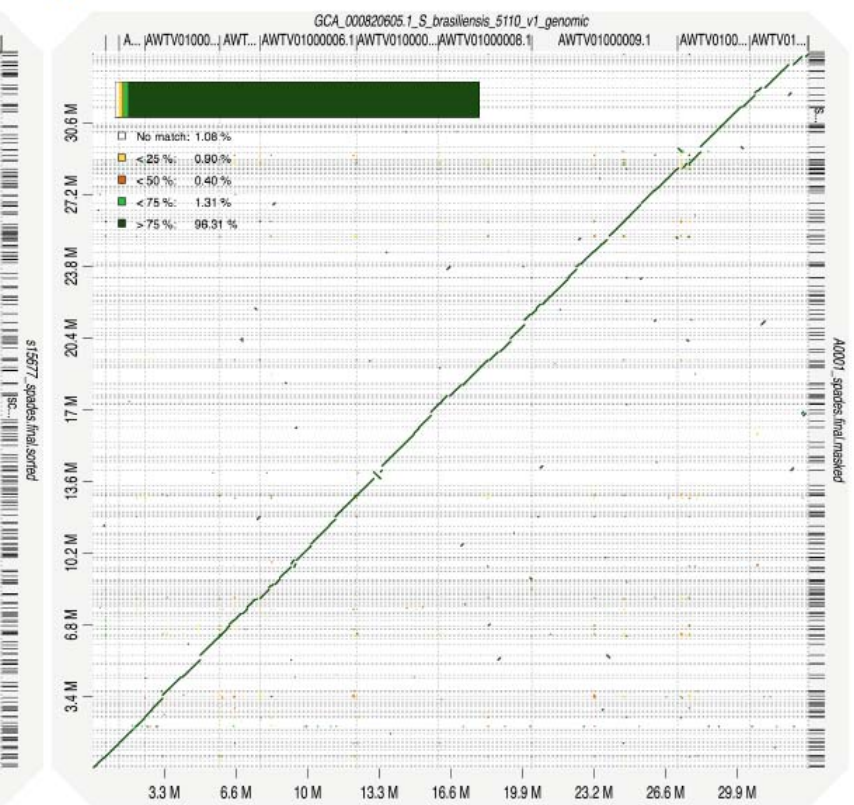

559 Supplementary Figure 1 - Dot plots of whole genome alignments between different $S$.

560 brasiliensis genotypes. The S. brasiliensis strains s15677 (A - RJ population) and A001 (B - FD

561 population) were aligned to the $S$. brasiliensis 5110 reference strain and the similarity values are 562 displayed for each scenario. 